\title{
Phenolic and Mineral Composition of Wild Chicory Grown in Romania
}

\begin{abstract}
GABRIELA STANCIU1', RAMONA ROTARIU1 ANTOANELA POPESCU2*, ANETA TOMESCU3
${ }^{1}$ OvidiusUniversity of Constanta, Department of Chemistry and Chemical Engineering, 124 Mamaia Blvd., 900527 Constanta, Romania

${ }^{2}$ Ovidius University of Constanta, Faculty of Pharmacy, 124 Mamaia Blvd., 900527, Constanta, Romania

${ }^{3}$ Ovidius University of Constanta, Faculty of Medicine, 124 Mamaia Blvd., 900527, Constanta, Romania

The paper presents original results concerning phenolic and mineral composition of different parts of wild chicory grown in Romania (flowers, leaves, stems and roots). Total and some individual phenols concentrations were determined using molecular absorption spectrometry (modified Folin Ciocalteu method) and HPLC-DAD. Metals concentrations were measured by FAAS. The highest total phenolic compounds concentration was founded in flowers (1531.2 mg GAE/100g d.w.), followed by leaves (1180.3 mg GAE/ $100 \mathrm{~g}$ d.w.), roots (167.86 mg GAE/100g d.w.) and stems (142.36 mg GAE/100g d.w.). HPLC-DAD analysis revealed the presence of seven phenolic acids in the range of 30-50\% from total phenols concentration. The main determined phenolic compounds are: in flowers methyl gallic acid ( $301.55 \mathrm{mg} / 100 \mathrm{~g} \mathrm{~d} . \mathrm{w}$.) in leaves, roots and stems ellagic acid (389.68 $\mathrm{mg} / 100 \mathrm{~g}$ d.w., $67.93 \mathrm{mg} / 100 \mathrm{~g}$ d.w. respectively $22.97 \mathrm{mg} / 100 \mathrm{~g} \mathrm{~d} . \mathrm{w}$.). Metals analyses by FAAS indicate that $\mathrm{Cd}, \mathrm{Cr}, \mathrm{K}, \mathrm{Ni}$ and $\mathrm{Pb}$ are in concentrations under the detection limits. Except iron and sodium, all others metals are in higher concentration in leaves. Rank for the metal concentration from chicory was $\mathrm{Ca}>\mathrm{Mg}>\mathrm{Zn}>\mathrm{Na}>\mathrm{Cu}>\mathrm{Fe}>\mathrm{Mn}$.
\end{abstract}

Keywords: chicory, TPC, phenolic acids, metals, HPLC - DAD, FAAS

The history of medicinal plants is associated with the evolution of civilization. In all regions of the world, the history of nations shows that these plants have always occupied an important place in medicine, in the composition of perfumes and in culinary preparations. Common chicory (Cichorium intybus) is a perennial, edible herbaceous plant belonging to the genus Cichorium of the Asteraceae family. It is known from antiquity: in ancient Egypt it was cultivated as a medicinal plant, being used to treat hepato-biliary and renal diseases [1].

Chicory usually grows like a weed or flower and the whole plant has numerous applications in food industry and medicine. Its dried roots were used as a substitute or adulterant in coffee pow der, the young leaves can be added to salads and vegetable dishes, while chicory extracts are used for the production of invigorating beverages. Wild chicory is used for winter forage for ruminant animal [2, 3]. It has been reported that this plant is an important source of fructans and chicoric acid, saccharides, organic acids, polyphenols such as chlorogenic acid, caffeic acid derivatives $[4,5]$. Because of its rich content of biologically active substances such as inulin, coumarins, vitamins, bitter compounds, flavonoids and sesquiterpene lactones, the whole plant extracts are used as anti-diabetic [6], antioxidant [7-9], antibacterial [10], antihepatotoxic [11], antiulcerogenic, antiinflammatory, appetizer, digestive, stomachic, different diseases connected with gastrointestinal system [12]. Chicory roots have been used in folk medicine for livers disorders gallstone and inflammations of the urinary tract since 17 th century [ 13 , 14]. Leaves and roots of Cichorium intybus L. were also used for purification of blood, for curing arteriosclerosis and they are also considered to possess anti-arthritis, antispasmodic, hypotensive and laxative action [15,16]. In addition, chicory extracts possess insecticidal activity [17].

Lately, there is a growing interest in natural plant extracts with potential antioxidant activity, because of their improved healthy effect [2, 18 - 24]. It is well known that polyphenols from plant extracts possessed strong antioxidant activities. However, not only phenolic compounds can be responsible for the antioxidant activity of chicory preparations. For instance, some authors suggest that sugars themselves, especially sucrose and fructans, can also act as radical scavengers in plant cells [25].

Heavy metals such as $\mathrm{Cr}, \mathrm{Cu}, \mathrm{Fe}, \mathrm{Mn}, \mathrm{Mo}, \mathrm{Ni}, \mathrm{V}$, and $\mathrm{Zn}$ are required in minute quantities by organisms, excessive amounts of these elements can become harmful to organisms. $\mathrm{Pb}, \mathrm{Cd}, \mathrm{Hg}$, and As do not have any beneficial effect on organisms and are thus regarded as the main threats since they may be poisonous or toxic and cause harm to living things. Metals accumulate in ecological food chain through uptake at primary producer level and then through consumption at consumer levels and plants roots are the primary contact site for heavy metal ions [26].

Most scientific papers present the determination of biologically active compounds and metals in extracts obtained from chicory roots or leaves. Multiple research papers have been published describing the phytochemical composition and several health properties of chicory, including antidiabetic, wound healing and antioxidant capacities of chicory grown in various countries, except Romania [2, 17, 18, 25, 27, 28].

The paper aims to present original results concerning analytical characteristics of methanolic macerates obtained from root, stem, leaves and flowers of wild chicory grown in Romania as well as metals concentration in different parts of the plant.

\section{Experimental part \\ Materials}

The Cichorium intybus plants were picked up in June 2018 at full bloom, thoroughly washed with distilled water and naturally dried on nets situated in an airy space. Subsequently, dry plant material was ground into a fine powder using a laboratory mill.

To perform the investigations, methanolic macerates have been prepared using $5 \mathrm{~g}$ of dry plant material (root, steam, leaves and flowers) of chicory that was vigorously mixed with $50 \mathrm{~mL}$ of methanol, maintained for 4 days at dark then filtered on Millipore paper. The macerates have been analyzed for total phenols concentration (TPC) in J une

* email: antoniapopescu2002@yahoo.co.uk 
and October to verify the stability in time. The same macerates have been analyzed in October for individual phenolic compounds using HPLC-DAD method.

For metals concentration determination by AAS, 0.5 of plant materials have been mineralized with $5 \mathrm{~mL}$ nitric acid and $40 \mathrm{~mL}$ deionized water to $120^{\circ} \mathrm{C} 130 \mathrm{~min}$, filtered in $50 \mathrm{~mL}$ volumetric flasks and filled up with water.

\section{Chemicals}

All used reagents were of analytical reagent grade. Gallic acid was purchased from Fluka (Buchs, Switzerland) and Folin - Ciocalteu reagent from Merck (Darmstadt, Germany). Gallic acid (standard phenolic compound) $1 \times 10^{-2} \mathrm{~mol} \mathrm{~L}^{-1}$ solution was prepared by dissolving 376 $\mathrm{mg}$ of gallic acid in $100 \mathrm{~mL}$ of ethanol. Folin -Ciocalteu reagent was diluted with distilled water $1: 2(\mathrm{~V}: \mathrm{V})$.

\section{Measurements and equipment}

Molecular spectrometric measurements of TPC were carried out using a UV-Vis Jasco V550 scanning spectrophotometer. The conditions of Folin Ciocalteu determination are those presented in [20]. The calibration curve with gallic acid as standard was linear in $0-4.76 \mathrm{mg}$ $\mathrm{GAE} / \mathrm{L}$ range and the correlation coefficient was 0.9987 (fig.1). The acronym GAE means the gallic acid equivalents.

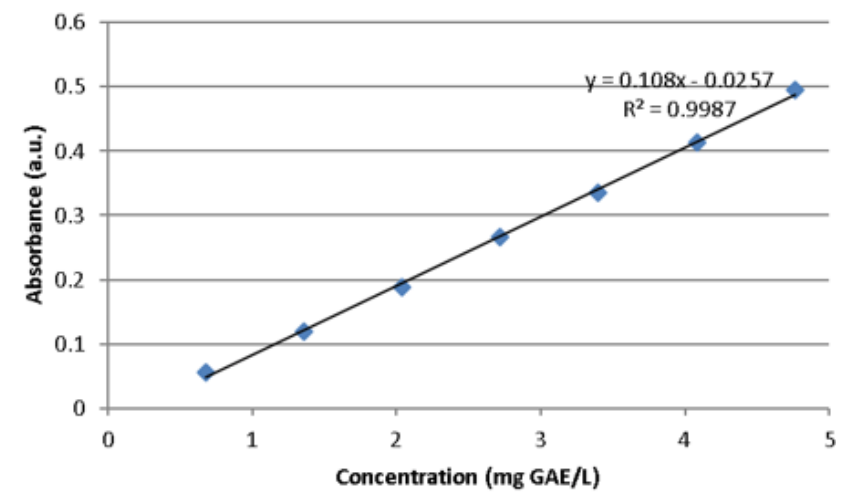

Fig.1. Calibration curve using gallic acid as standard for TPC determination in chicory

The identification and quantitative determination of phenolic compounds was performed using HPLC system (Agilent 1200) with quaternary pump, DAD, auto sampler. The conditions of individual phenolic compounds separation, identification and quantification have been presented in our previous work [29]. The retention times and correlation coefficients of calibration curves for individual founded phenolic acids are presented in table 1.

Table 1

THE CHARACTERISTICS OF IDENTIFICATION AND QUANTIFICATION OF INDIVIDUAL PHENOLIC COMPOUNDS BY HPLC-DAD

\begin{tabular}{|l|c|l|l|}
\hline No. & Phenolic compound & $\begin{array}{l}\text { Retention time } \pm \\
\text { SD, min }\end{array}$ & $\mathrm{R}^{2}$ \\
\hline 1 & Gallic acid & $0.990 \pm 0.025$ & 0.99537 \\
\hline 2 & Methyl gallic acid & $2.606 \pm 0.008$ & 0.99563 \\
\hline 3 & Chlorogenic acid & $3.501 \pm 0.015$ & 0.99999 \\
\hline 4 & Caffeic acid & $4.598 \pm 0.036$ & 0.99619 \\
\hline 5 & p- Coumaric acid & $7.187 \pm 0.019$ & 0.99798 \\
\hline 6 & Ellagic acid & $15.303 \pm 0.027$ & 0.99885 \\
\hline 7 & Cinnamic acid & $15.867 \pm 0.007$ & 0.99845 \\
\hline
\end{tabular}

Atomic absorption measurements for metal concentrations were performed with a spectrometer ContrAA ${ }^{\circledR} 700$ using flame technique. A Certipure multielement standard solution from Merck $(1 \mathrm{mg} / \mathrm{mL}$ of each metal) was used for calibration. In order to ensure the quality of analytical data, the following performance parameters have been determined: concentration domain $(\mu \mathrm{g} / \mathrm{L})$ and correlation coefficients of the calibration curve $\left(R^{2}\right)$, limits of detection (LOD), limits of quantitation (LOQ) (table 2).

Table 2

PERFORMANCE PARAMETERS FOR AAS MEASUREMENTS

\begin{tabular}{|l|l|l|l|l|}
\hline Metal & $\begin{array}{l}\text { Concentration } \\
\text { domain }(\mathrm{mg} / \mathrm{L})\end{array}$ & $\mathrm{R}^{2}$ & $\begin{array}{l}\text { LOD } \\
(\mathrm{mg} / \mathrm{L})\end{array}$ & $\begin{array}{l}\text { LOQ } \\
(\mathrm{mg} / \mathrm{L})\end{array}$ \\
\hline Cadmium & $0.050-1.000$ & 0.9938 & 0.0099 & 0.0693 \\
\hline Calcium & $40.00-200.00$ & 0.9990 & 84.13 & 116.1 \\
\hline Chromium & $0.050-2.000$ & 0.9902 & 0.0112 & 0.0503 \\
\hline Copper & $0.050-2.000$ & 0.9991 & 0.0533 & 0.0586 \\
\hline Iron & $0.050-2.000$ & 0.9995 & 0.0473 & 0.1183 \\
\hline Lead & $0.200-8.000$ & 0.9996 & 0.1371 & 1.0280 \\
\hline Magnesium & $1.000-5.000$ & 0.9932 & 0.6440 & 2.2070 \\
\hline Manganese & $0.050-2.000$ & 0.9953 & 0.0099 & 0.0597 \\
\hline Nickel & $0.100-4.000$ & 0.9969 & 0.0233 & 0.1051 \\
\hline Potassium & $1.000-5.000$ & 0.9820 & 1.290 & 4.585 \\
\hline Sodium & $5.000-25.000$ & 0.9966 & 1.282 & 4.669 \\
\hline Zinc & $0.050-1.000$ & 0.9922 & 0.0430 & 0.1076 \\
\hline
\end{tabular}

\section{Results and discussions}

Phenolics or polyphenols are secondary plant metabolites that are ubiquitously present in plants and their products. Many of them have been shown to contain high levels of antioxidant activities. Due to their redox properties these compounds contribute to the overall antioxidant activities of plants [27, 30-32].

The obtained results about TPC determined by the modified Folin Ciocalteu method are presented in table 3. The determinations have been done in June and October using the same methanolic macerates stored at $4^{\circ} \mathrm{C}$ to dark. A very slight decrease of TPC can be noticed in all samples, which proves the stability of methanolic macerates in time.

Table 3

TOTAL PHENOLS CONCENTRATION IN CHICORY IN JUNE AND OCTOBER 2018

\begin{tabular}{|c|c|c|}
\hline \multirow{2}{*}{ Chicory part } & \multicolumn{2}{|c|}{ TPC, mgGAE $100 \mathrm{~g} \mathrm{dw}$} \\
\cline { 2 - 3 } & June 2018 & October 2018 \\
\hline Roots & 167.86 & 158.7 \\
\hline Stems & 142.36 & 140.4 \\
\hline Leaves & 1180.3 & 1174.5 \\
\hline Flowers & 1531.2 & 1468.5 \\
\hline
\end{tabular}


Table 4

CONTENTS (mg/100g d.w.) AND WEIGHT PERCENTAGES ( $w$ t\%) OF INDIVIDUAL PHENOLIC COMPOUNDS OF TESTED CHICORY PARTS DETERMINED BY HPLC-DAD

\begin{tabular}{|c|c|c|c|c|c|c|c|c|}
\hline \multirow[t]{2}{*}{ Phenolic compound } & \multicolumn{2}{|c|}{ Flowers } & \multicolumn{2}{|c|}{ Leaves } & \multicolumn{2}{|c|}{ Steams } & \multicolumn{2}{|c|}{ Roots } \\
\hline & $\begin{array}{c}\mathrm{mg} / \\
100 \mathrm{~g} \mathrm{~d} . w .\end{array}$ & wt $\%$ & $\begin{array}{l}\mathrm{mg} / \\
100 \mathrm{~g} \\
\mathrm{~d} . \mathrm{w} .\end{array}$ & wt $\%$ & $\begin{array}{l}\mathrm{mg} / \\
100 \mathrm{~g} \\
\mathrm{~d} . \mathrm{w} .\end{array}$ & $\mathrm{wt} \%$ & $\begin{array}{c}\mathrm{mg} / \\
100 \mathrm{~g} \mathrm{~d} . w .\end{array}$ & $w t \%$ \\
\hline Chlorogenic acid & 47.27 & 6.40 & 25.70 & 5.38 & 1.71 & 4.12 & 1.31 & 1.57 \\
\hline Caffeic acid & 7.46 & 1.01 & 0.83 & 0.17 & 1.24 & 2.99 & 0.77 & 0.92 \\
\hline Gallic acid & 165.41 & 22.38 & 55.07 & 11.53 & 10.73 & 25.87 & 8.39 & 10.03 \\
\hline Methyl gallic acid & 301.55 & 40.80 & - & - & - & - & - & - \\
\hline Cinnamic acid & 15.80 & 2.13 & 6.18 & 1.29 & 4.22 & 10.17 & 4.74 & 5.67 \\
\hline Ellagic acid & 192.35 & 26.02 & 389.68 & 81.59 & 22.97 & 55.38 & 67.93 & 81.20 \\
\hline p-Coumaric acid & 9.32 & 1.26 & 0.17 & 0.04 & 0.61 & 1.47 & 0.52 & 0.62 \\
\hline Total phenols & 739.16 & 100 & 477.63 & 100 & 41.48 & 100 & 83.66 & 100 \\
\hline
\end{tabular}

The highest TPC value was registered in flowers, followed by leaves, roots and the smallest in stems. Our results are in good agreement with other published data regarding TPC in chicory $[2,5,7,18,27]$. It can be mentioned that little data are published about the characteristics of flowers and stems.

In the methanolic macerates of flow ers, leaves, steams and roots of chicory there were identified and quantified seven individual phenolic compounds in different concentrations using HPLC - DAD method.

Table 4 presents the individual phenols concentrations determined by HPLC - DAD expressed in $\mathrm{mg} / 100 \mathrm{~g}$ d.w. and percentages $(\%)$.

The maximum of total identified phenolic compounds concentration is registered also in flowers $(739.16 \mathrm{mg} /$ $100 \mathrm{~g}$ d.w.) and the minimum in stems $(41.48 \mathrm{mg} / 100 \mathrm{~g}$ d.w.). In flowers, the main phenolic compound is methyl gallic acid and in leaves, stems and roots ellagic acid.

Table 5 presents the weight calculated percentages of measured total individual phenols by HPLC reported to TPC values.

As table 5 shows, in the present study there were identified only $30-52 \%$ of individual phenolic compounds existing in chicory.
Plants can uptake the toxic metals, which can rout to the human body via herbal preparation and may cause serious health hazards to human life [33]. As a consequence, the control of metal concentrations in plants is an important issue in order to assure the quality of life.

Table 6 presents the results of our researches concerning the metals concentrations in flowers, leaves, roots and stems of chicory.

Among 12 metals considered for analysis, there were 5 $(\mathrm{Cd}, \mathrm{Cr}, \mathrm{K}, \mathrm{Ni}$ and $\mathrm{Pb})$ with concentrations under the detection limit. Except iron and sodium, all others metals are in higher concentration in leaves.

Calcium is an essential element for all higher plants and is found in relatively large quantities in plant leaves but plants differ widely in the amounts of calcium they need. Calcium, in the form of calcium pectate, is an important component of plant cell walls. Calcium was determined to be between $5767 \mathrm{mg} / \mathrm{kg}$ in flowers (minimum) and $13160 \mathrm{mg} / \mathrm{kg}$ in leaves (maximum). Of all the analyzed metals, calcium recorded the highest concentrations.

Although not essential for most plants, sodium can be beneficial to plants in many conditions, particularly when potassium is deficient. As such it can be regarded a nonessential or functional nutrient. At low levels, $\mathrm{Na}^{+}$not only

\begin{tabular}{|c|c|c|c|c|}
\hline \multirow[t]{2}{*}{ No. } & \multirow[t]{2}{*}{ Sample } & \multirow{2}{*}{$\begin{array}{l}\text { Percent of measured } \\
\text { individual phenols by } \\
\text { HPLC versus TPC, wt } \%\end{array}$} & \multicolumn{2}{|c|}{$\begin{array}{c}\text { The major individual } \\
\text { determined phenol in chicory }\end{array}$} \\
\hline & & & phenolic acid & wt $\%$ \\
\hline 1 & Flowers & 50.33 & Methyl gallic acid & 20.53 \\
\hline 2 & Leaves & 40.66 & Ellagic acid & 33.17 \\
\hline 3 & Steams & 29.54 & Ellagic acid & 16.36 \\
\hline 4 & Roots & 52.72 & Ellagic acid & 42.80 \\
\hline
\end{tabular}

\begin{tabular}{|c|c|c|c|c|}
\hline \multirow{2}{*}{ Metal } & \multicolumn{4}{|c|}{ Chicory part } \\
\cline { 2 - 5 } & Flowers & Leaves & Roots & Stems \\
\hline $\mathrm{Ca}, \%$ & 0.58 & 1.32 & 0.50 & 0.65 \\
\hline $\mathrm{Cu}, \mathrm{mg} / \mathrm{kg}$ & $11.37 \pm 0.01$ & $14.54 \pm 0.04$ & $12.64 \pm 0.02$ & $8.20 \pm 0.03$ \\
\hline $\mathrm{Fe}, \mathrm{mg} / \mathrm{kg}$ & $15.19 \pm 0.01$ & $12.13 \pm 0.02$ & $1.75 \pm 0.01$ & $5.57 \pm 0.02$ \\
\hline $\mathrm{Mg}, \mathrm{mg} / \mathrm{kg}$ & $435.3 \pm 0.01$ & $648.2 \pm 0.01$ & $24.76 \pm 0.04$ & $443.00 \pm 0.03$ \\
\hline $\mathrm{Mn}, \mathrm{mg} / \mathrm{kg}$ & $3.34 \pm 0.01$ & $4.00 \pm 0.02$ & $0.42 \pm 0.02$ & $0.68 \pm 0.01$ \\
\hline $\mathrm{Na}, \mathrm{mg} / \mathrm{kg}$ & $11.10 \pm 0.04$ & $19.89 \pm 0.04$ & $8.012 \pm 0.04$ & $28.23 \pm 0.04$ \\
\hline $\mathrm{Zn}, \mathrm{mg} / \mathrm{kg}$ & $9.93 \pm 0.01$ & $19.92 \pm 0.01$ & $12.07 \pm 0.01$ & $19.00 \pm 0.01$ \\
\hline
\end{tabular}

Table 5

THE WEIGHT PERCENTAGES (\%) OF TOTAL PHENOLS AND OF MAJOR PHENOLIC COMPOUND DETERMINED IN CHICORY

Table 6

METALS CONCENTRATION (mg/100g dw) IN CHICORY COLLECTED IN JUNE 2018 
is harmless but can be very useful, particularly in low $\mathrm{K}^{+}$ conditions. This is because, in hydrated form, $\mathrm{Na}^{+}$and $\mathrm{K}^{+}$ are chemically and structurally very similar. Thus, many of the roles that $\mathrm{K}^{+}$plays in plant cells, including some of the metabolic ones, can therefore be fulfilled by $\mathrm{Na}^{+}$[34]. Sodium concentration in chicory ranged from $8.012 \mathrm{mg} /$ $\mathrm{kg}$ in roots to 28.23 in stems.

Magnesium is a constituent of every chlorophyll molecule, and therefore essential for photosynthesis, green plants cannot do without it. In chicory samples, magnesium varied from $24.6 \mathrm{mg} / \mathrm{kg}$ in roots to $648.2 \mathrm{mg} /$ $\mathrm{kg}$ in leaves.

Iron as an essential element for all plants has many important biological roles in the processes as diverse as photosynthesis, chloroplast development and chlorophyll biosynthesis. Iron and manganese both play an important role in plant growth and development, but often compete for absorption, as an abundance of one of these micronutrients makes the other less available to plant roots. $\mathrm{Mn}$ is readily transported from root to shoot through the transpiration stream, but not readily remobilized through phloem to other organs after reaching the leaves. Excess $\mathrm{Mn}$ is reported to inhibitsynthesis of chlorophyll by blocking a Fe concerning process [26].

Fe concentration in chicory ranged from 1.75 to 15.19 $\mathrm{mg} / \mathrm{kg}$; maximum was found in chicory flowers. Manganese was found between 0.68 and $4.00 \mathrm{mg} / \mathrm{kg}$, with maximum in leaves, too.

Copper is an essential metal for normal plant growth and development considered as micronutrient, although it is also potentially toxic [34].

Concentration of Cu ranged from 8.20 to $14.54 \mathrm{mg} / \mathrm{kg}$ in analyzed samples, under $15 \mathrm{mg} / \mathrm{kg}$, the permissible limit of the World Health Organisation [35]. Chicory leaves accumulate higher concentration of $\mathrm{Cu}$ compared to the roots due to the uptake of soluble toxic elements to the foliar parts of plants.

Zinc is an essential micronutrient that affects several metabolic processes of plants and has a long biological half-life. The function of zinc is to help a plant to produce chlorophyll [26].

Zn concentration was found highest in leaves $19.92 \mathrm{mg} /$ $\mathrm{kg}$, while in flowers was $9.93 \mathrm{mg} / \mathrm{kg}$. Zn concentration should not increase the $200 \mathrm{mg} / \mathrm{kg}$ and its concentration was found in the range of permissible limit.

Rank for the metal concentration from chicory was $\mathrm{Ca}>\mathrm{Mg}>\mathrm{Zn}>\mathrm{Na}>\mathrm{Cu}>\mathrm{Fe}>\mathrm{Mn}$.

\section{Conclusions}

Original results concerning individual and total phenolic and mineral composition of different parts of wild chicory (Cichorium intybus) from Romania (flowers, leaves, stems and roots) are presented for the first time.

The methanolic macerates showed stability after four months as total phenolics concentration values confirmed. The highest total phenolic acids concentration was founded in flowers (1531.2 mg GAE/100g d.w.), followed by leaves (1180.3 mg GAE/100g d.w.), roots (167.86 mg GAE/100g d.w.) and stems (142.36 mg GAE/100g d.w.). Our obtained data agree with the published results of other authors. HPLC-DAD analysis revealed the presence of seven phenolic acids in the range of $30-50 \%$ percentage versus TPC. The main determined phenolic compounds are: in flowers methyl gallic acid ( $301.55 \mathrm{mg} / 100 \mathrm{~g}$ d.w.) and in leaves, roots and stems ellagic acid $(389.68 \mathrm{mg} / 100 \mathrm{~g}$ d.w., $67.93 \mathrm{mg} / 100 \mathrm{~g}$ d.w. respectively $22.97 \mathrm{mg} / 100 \mathrm{~g}$ d.w.).

Metals analyses by FAAS indicate that $\mathrm{Cd}, \mathrm{Cr}, \mathrm{K}, \mathrm{Ni}$ and $\mathrm{Pb}$ are in concentrations under the detection limits. Except iron and sodium, all others metals are in higher concentration in leaves.

Rank for the metal concentration from chicory was $\mathrm{Ca}>\mathrm{Mg}>\mathrm{Zn}>\mathrm{Na}>\mathrm{Cu}>\mathrm{Fe}>\mathrm{Mn}$.

Due to good phenolic and mineral composition, wild chicory would be an important candidate in pharmaceutical formulations and plays an important role in improving the human health by participating in the antioxidant defense system against free radical generation.

\section{References}

1.DAS S., VASUDEVA N., SHARMA S., Drug Dev Ther, 7, 2016, p.1

2.DENEV P., PETCOVA N., IVANOV I., SIRAKOV B., VRANCHEVA R., PAVLOV A., Scientific Bulletin. Series F. Biotechnologies, 18, 2014, p.124.

3.GAGGIA F., MATTARELLI P., BIAVATI B., Int. J. Food Microbiol. 141, 2010, p. S15.

4.MILALA J., GRZELAK-BLASZCZYK K., KROL B., JUSKIEWICZ J ., ZDUNCZYK Z., Pol. J. Food Nutr. Sci., 59, 2009, p.35.

5.MASSOUD M.I., AMIN W.A., ELGINDY, A. A, J. Adv. Agric. Res. 14 (3), 2009, p. 735.

6.AZIZI-FINIA I., ADIB-HAJBAGHERYB M., GHAREHBOGHLOU Z., Eur. J. Integr. Med. 8, 2016, p.570.

7.CONFORTI F., SOSA S., MARRELLI M., MENICHINI F., STATTI G.A., UZUNOV D., TUBARO A., MENICHINI F., Food Chem. 112, 2009, p. 587. 8.PAPETTI A. MAIETTA M., CORANA F., MARRUBINI G., GAZZANI G., J. Food Comp. Anal. 63, 2017, p.189.

9.TARDUGNO R., POZZEBON M., BEGGIO M. DEL TURCO P., POJ ANA G., Food Chem. 266, 2018, p.175.

10.REHMAN A., ULLAH N., ULLAH H, AHMAD I., Asian Pac. J. Trop. Dis. 4 (Suppl 2) 2014, p. $S 943$.

11.GUO-YU LI, YA-XIN ZHENG, FU-ZHOU SUN, JIAN HUANG, MENGMENG LOU, JING-KAI GU, JIN-HUI WANG, Int. J. Mol. Sci. 16, 2015 p. 22190.

12.STREET R.A., SIDANA J., PRINSLOO G., Evidence-Based Complementary and Alternative Medicine, 2013, ID 579319, http:// dx.doi.org/10.1155/2013/579319

13.LOPEZ-MUNOZ F., ALAMO C., GARCIA-GARCIA P., J. Ethnopharmacol. 106, 2006, p. 429.

14.SCHMIDT B.M., ILIC N., POULEV A., RASKIN I., Food Chem. Toxicol. 245, 2007, p. 1131.

15.CHOW J., J Ren Nutr 12, 2002, p. 76.

16.LIN Z., ZHANG B., LI L., WANG H., ZHU C., Integr. Med Res, 4(1S) 2015 p.2

17.MANSOUR S.A., IBRAHIM R.M. EL-GENGAIHI, Ind. Crop Prod. 54, 2014, p. 192.

18.DALAR A., KONCZAK I., Ind. Crop Prod. 60, 2014, p.79.

19.STANCIU, G., CHIRILA, E., DOBRINAS, S., NEGREANU-PIRJ OL, T., Rev. Chim (Bucharest), 61, no.1, 2010, p. 41.

20.STANCIU G., OANCEA I.A., OANCEA E., CHIRILA E., Rev. Roum. Chim. 62 (6-7), 2017, p. 553.

21.STANCIU, G., CRISTACHE, N., LUPSOR, S., DOBRINAS, S., Rev. Chim (Bucharest), 68, no. 7, 2017. p.1429.

22.0ANCEA, I.A., OANCEA, E., UNGUREANU, E-M., STANCIU, G., CHIRILA, E., Rev. Roum. Chim. 62 (6-7), 2017, p. 511.

23.DOBRINAS S., STANCIU G., LUPSOR S., J ournal of Science and Arts 2, 2017, p. 321

24.STANCIU G., LUPSOR S., POPESCU A., OANCEA IA., Journal of Science and Arts 1, 2017, p. 107.

25.JURGONBSKI A., MILALA J ., JUSBKIEWICZ J , ZDUNBCZYK Z., KROL B., Food Technol. Biotechnol. 49 (1), 2011, p. 40.

26.ASATI A., PICHHODE M., NIKHIL K., Int. J. Application Innovation Eng. Manag. 5(3), 2016, p.56.

27.ABBASZ.K., SAGGU S., SAKERAN M.I., ZIDAN N., REHMAN H., ANSARI A.A., Saudi J. Biol. Sci. 22, 2015, p.322.

28.CARAZZONE C., MASCHERPA D., GAZZANI G., PAPETTI A., Food Chem. 138, 2013, p. 1062. 
29.STANCIU, G., LUPSOR, S. TOMESCU, A. SIRBU, R., Rev. Chim (Bucharest) (in press)

30.ANDRICA, F.M., DRAGHICI, G.A., SOICA, C., PINZARU, I., CORICOVAC, D., CITU C., DEHELEAN C., Rev. Chim (Bucharest), 67, no. 2, 2016, p. 289.

31.PALLAG, A.M., JURCA, T., PASCA, B., SIRBU, V., HONIGES, A., COSTULEANU, M., Rev. Chim (Bucharest), 67, no. 8, 2016, p.1623
32.LUNGU, L., SAVOIU, M.R., MANOLESCU, B.N., FARCASANU, I.C., POPA, C.V., Rev. Chim (Bucharest), 67, no, 10, 2016, p.1928.

33.MAATHUIS F.J.M., J. Exp. Bot 65(3), 2014, p.849.

34. MAHMOOD A., RASHID S., MALIK R.N., J. Ethnopharmacol.148, 2013, p.158.

35.*** WHO, 1999. Monographs on Selected Medicinal Plants, vol. 1. World Health Organization, Geneva, Switzerland, 1999.

$\overline{\text { Manuscript received: 26. 07. } 2018}$ 